\title{
Effect of Competitive Anxiety on Passing Decision-Making in Under-17 Soccer Players
}

\author{
Leonardo de Sousa Fortes ${ }^{1}$, Raphaella Christinne Ribeiro de Lima², \\ Sebastião Sousa Almeida ${ }^{3}$, Romulo Maia Carlos Fonseca ${ }^{1}$, \\ Pedro Pinheiro Paes ${ }^{1}$, Maria Elisa Caputo Ferreira ${ }^{4}$ \\ ${ }^{1}$ Universidade Federal de Pernambuco, Recife-PE, Brazil \\ ${ }^{2}$ Universidade Federal de Pernambuco, Vitória de Santo Antão-PE, Brazil \\ ${ }^{3}$ Universidade de São Paulo, Ribeirão Preto-SP, Brazil \\ ${ }^{4}$ Universidade Federal de Juiz de Fora, Juiz de Fora-MG, Brazil
}

\begin{abstract}
It is not known if competitive anxiety affects decision-making performance in athletes. This study aimed to analyze the effect of competitive anxiety on passing decision-making in young soccer players. This is a prospective study, whose sample consisted of 40 soccer athletes of the under-17 category. The Portuguese version of the Competitive State Anxiety Inventory (CSAI-2R) was filled out by athletes 45 minutes before the start of a soccer match. Decision-making was evaluated in a real game situation. The analysis and categorization of actions were based on the Game Performance Assessment Instrument. The results showed significant influence of cognitive anxiety $\left(R^{2}=.20 ; p=.001\right)$, somatic anxiety $\left(R^{2}=.45 ; p=.001\right)$ and self-confidence about the passing decisionmaking index $\left(R^{2}=.31 ; p=.001\right)$. It was concluded that competitive anxiety can be considered an intervening factor in decisionmaking of the pass of young male soccer players.Keywords: test validity, scaling, elderly, depression
\end{abstract}

Keywords: sports psychology, anxiety, soccer, athletes

\section{Efeito da Ansiedade Competitiva Sobre a Tomada de Decisão do Passe em Atletas de Futebol da Categoria Sub-17}

\begin{abstract}
Resumo: Não se sabe se a ansiedade competitiva acarreta efeito no desempenho da tomada de decisão em atletas. O objetivo do estudo foi analisar o efeito da ansiedade competitiva sobre a tomada de decisão do passe em jovens atletas de futebol. Trata-se de uma investigação prospectiva, cuja amostra foi composta por 40 atletas de futebol da categoria sub-17. A versão em língua portuguesa do Competitite State Anxiety Inventory (CSAI-2R) foi preenchida 45 minutos antes do início de uma partida de futebol. A tomada de decisão foi avaliada pelos critérios do Game Performance Assessment Instrument. Os resultados apontaram influência significativa da ansiedade cognitiva $\left(R^{2}=.20 ; p=.001\right)$, da ansiedade somática $\left(R^{2}=.45 ; p=.001\right)$ e da autoconfiança sobre o índice de tomada de decisão do passe $\left(R^{2}=.31 ; p=.001\right)$. Concluiu-se que a ansiedade competitiva pode ser considerada um fator interveniente na tomada de decisão do passe de jovens atletas de futebol do sexo masculino.
\end{abstract}

Palavras-chave: psicologia do esporte, ansiedade, futebol, atletas

\section{Efecto de la Ansiedad Competitiva Sobre Toma de Decisiones de lo Pase en los Jugadores de Fútbol de la Categoría Menores de 17 Años}

Resumen: No se sabe si la ansiedad competitiva genera efectos en el rendimiento de toma de decisiones en los atletas. El objetivo del estudio fue analizar el efecto de la ansiedad competitiva sobre toma de decisiones del pase en futbolistas jóvenes. Se trata de una investigación prospectiva, cuya muestra fue formada por 40 jugadores de la categoría sub-17. La versión en portugués del Competitive State Anxiety Intentory se completó 45 minutos antes del comienzo de una partida de fútbol. La toma de decisiones se evaluó mediante los criterios del instrumento de evaluación del rendimiento del juego por medio del Game Performance Assessment Instrument. Los resultados mostraron una influencia significativa de la ansiedad cognitiva $\left(R^{2}=.20 ; p=.001\right)$, de la ansiedad somática $\left(R^{2}=.45 ; p=.001\right)$ y de la autoconfianza sobre el índice de toma de decisión del pase $\left(R^{2}=.31 ; p=.001\right)$. Se concluyó que la ansiedad competitiva puede considerarse un factor que interviene en la toma de decisiones del pase de jóvenes jugadores de fútbol de sexo masculino.

Palabras clave: psicología del deporte, ansiedad, futbol, atletas

Correspondence address: Leonardo de Sousa Fortes. Universidade Federal de Pernambuco. Programa de Pós-Graduação em Educação Física. Avenida Professor Moraes Rego, no 1235, Iputinga, Recife-PE, Brazil. CEP 50.670-901. E-mail: leodesousafortes@hotmail.com
Soccer is a collective sport of the intermittent type, and makes high demands on energy, due to the motor actions undertaken, which vary in intensity and duration during the game (Pedro, Machado, \& Nakamura, 2014). Its technical-tactical 
actions do not have a constant pattern during the games, as a result of which the motor activities during the match are abruptly interrupted and then re-begun various times in a random manner (Müller, Garganta, Santos, \& Teoldo, 2016). In this regard, soccer is indicated as a dynamic, highly unpredictable sport: requiring appropriate decision-making in order to obtain success (Romeas, Guldner, \& Faubert, 2016).

Decision-making relates to a skill of the human brain in extracting information from the visual scenario. This information is considered essential for good performance in unpredictable sports (Romeas et al., 2016). According to Afonso, Garganta and Mesquita (2012), decisionmaking depends on visual perception, focusing attention, anticipation and memory. Equally, it is worth emphasizing that motor action can influence the result of the decisionmaking (Lopes, Magalhães, Diniz, \& Albuquerque, 2016), mainly in young athletes.

Normally, the cognitive component of athletes' decisionmaking ("what to do") is evaluated through the use of videos, which simulate situations which occur during a game. This type of analysis is known as "declarative tactical knowledge" (Matias \& Greco, 2011). However, according to Memmert and Harvey (2008), decision-making involves both the cognitive and motor aspects. This being the case, the recommendation is to use a test which simulates game situations and also involves motor actions - for example, the Game Performance Assessment Instrument (GPAI), developed by Oslin, Mitchell and Griffin (1998), and adapted by Memmert and Harvey (2008).

Researchers state that athletes' decision-making is mainly developed during the phase of adolescence (Borges, Avelar, \& Rinaldi, 2015). Hence, it is necessary to identify the intervening factors in athletes' decision-making when they are still at a relatively young age - as, for example, in the junior teams. As a result, the use of aspects that positively influence athletes' decision-making, as well as the inhibition of factors which negatively affect it, could be implemented in the junior teams, with the premise of optimizing performance and decision-making in the sport. On the one hand, the scientific literature has shown that the situational methods employed in fields with reduced space are efficient for strengthening decision-making in athletes of collective sports characterized by unpredictability (Davids, Araújo, Correia, \& Vilar, 2013; Romeas et al., 2016). On the other hand, it seems that some emotions - including anxiety - can negatively affect athletes' decision-making (Gonzaga, Albuquerque, Malloy-Diniz, Greco, \& Costa, 2014).

Competitive anxiety, in its turn, is indicated as a multifactorial construct relating to the behavior regarding the stress response and a tendency to perceive stressing situations (Fernandes, Nunes, Raposo, \& Fernandes, 2014; Fernandes, Nunes, Raposo, Fernandes, \& Brustad, 2013; Fortes, Lira, Lima, Almeida, \& Ferreira, 2016). According to the Multidimensional Theory of Competitive State Anxiety (Martens, Vealey, \& Burton, 1990), anxiety has three components: cognitive, somatic, and self-confidence. Cognitive anxiety refers to the negative thoughts and expectations related to performance. Somatic anxiety relates to the affective and physiological elements of the experience of anxiety which directly affect the autonomous nervous system. Self-confidence refers to the conviction and feeling of ability to carry out actions required in the competition. To the best of our knowledge, studies have not yet been found evaluating the effect of these three components of competitive anxiety in decision-making in undertaking the basics of soccer in young athletes. Among these foundations, one recent study showed that the number of passes increased by $35 \%$ in the world cup soccer finals between 1966 and 2010; and that the successful teams in World Cup matches passed the ball more often (Wallace \& Norton, 2014).

From the practical point of view, this type of investigation could reveal the effect of competitive anxiety on passing decision-making in young soccer players. In this regard, the findings could be of extreme importance for coaches in this sport. In the light of these notes, the study aimed to analyze the effect of competitive anxiety on passing decision-making in young soccer players.

Considering the notes of researchers who specialize in the area of decision-making in sport (Afonso et al., 2012; Araújo et al., 2015), three hypotheses have been formulated: (a) the greater the intensity of the cognitive anxiety, the worse the performance will be in the passing decision-making; (b) the greater the intensity of the somatic anxiety, the worse the performance will be in the passing decision-making; and (c) the greater the intensity of self-confidence, the better the performance will be in the passing decision-making.

\section{Method}

\section{Participants}

This is a prospective investigation with follow-up of approximately 45 minutes, undertaken with young male soccer players. The sample was chosen non-probabilistically, being made up of 40 volunteers aged between 16 and 17 years old, participating in the Pernambuco under-17 category soccer championship. The participants belonged to four teams linked to the Pernambuco Soccer Federation. Only the outfield players who were not reserves in their teams took part in the study.

The athletes trained an average of two hours per day, four times a week. In order to be included in this research, the athletes had to: (a) have been soccer players for at least two years; (b) undertake systematic training in soccer for at least six hours per week; and (c) be enrolled in the state soccer championship in the under-17 category, organized by the Pernambuco Soccer Federation.

\section{Instruments}

The Brazilian version (Fernandes et al., 2013) of the Competitive State Anxiety Inventory (CSAI-2R) (Martens et al., 1990) was used to evaluate the athletes' competitive 
anxiety. The CSAI-2R is made up of 16 items which measure three subscales: cognitive anxiety, somatic anxiety, and selfconfidence. The score for each subscale is calculated by summing the answers to the items for each factor, divided by the respective number of items. The dimension of intensity of the CSAI-2R was adopted as the criteria for evaluating competitive anxiety. This is provided in a four-point Likert scale, varying from 1 (nothing) to 4 (a lot). The higher the score, the greater the intensity of the competitive anxiety. The decision was made to use the dimension of intensity of the CSAI-2R because this dimension analyzes the scale of the competitive anxiety at the exact moment at which the questionnaires are filled out. The CSAI-2R has been validated for Brazilian athletes and has shown excellent psychometric properties (Fernandes et al., 2013). For the present sample, internal consistency (evaluated using the Cronbach alpha) of $0.75,0.79$ and 0.77 was identified for the subscales of cognitive anxiety, somatic anxiety, and self-confidence, respectively.

Decision-making was evaluated in a real game situation. The participants played for two halves of 45 minutes, adopting the official soccer rules. The entire game was filmed using a CANON ${ }^{\circledR}$ camera (model SX60). The analysis and categorization of the actions were based in the GPAI (Memmert \& Harvey, 2008). The components of the passing decision-making in soccer, as proposed by Romeas et al. (2016), were adopted. Accordingly, the passing decisionmaking was considered to be appropriate when the pass was made to one of the player's team members who was not being marked at the time and: (a) either directly or indirectly set up the chance for a goal or; (b) was to a team member who was better placed than the player making the pass.

The index for passing decision-making was calculated according to the formula below, considering the changes suggested by Memmert and Harvey (2008). Each action was analyzed by two specialists who were experienced in soccer, and was classified as appropriate or inappropriate. The acceptable coefficient of agreement ( $k a p p a=0.97$; $p=0.01$ ) was identified for the two specialists' classifications.

$$
\begin{aligned}
& \text { Decision-making index }=\quad \frac{\left(a_{a}+10\right)}{\left(a_{a}+10\right)+\left(a_{i}+10\right)} \\
& a_{a}=\text { appropriate actions } \\
& a_{i}=\text { inappropriate actions }
\end{aligned}
$$

\section{Procedure}

Data collection. A priori, the researchers responsible contacted four coaches of four under-17 category soccer teams in the State of Pernambuco. The procedures, as well as the study aims, were duly explained and authorization was requested to carry out the investigation with their athletes. Following that, a meeting was held with the soccer players in order to clarify all the investigation's ethical procedures. At this meeting, the terms of free and informed consent (TFIC) were also handed over to the players' respective coaches for them to consent to their athletes' participation. All athletes signed the terms of assent, agreeing to their voluntary participation in the investigation.

The Brazilian version of the Competitive State Anxiety Inventory (CSAI-2R) (Fernandes et al., 2013) was filled out by the athletes 45 minutes before the beginning of a match (semifinals) in the male under-17 category of the Pernambuco Soccer Championship. Following that, the athletes went on to the field to undertake their warm-up with a ball $(\sim 20$ minutes' duration). After that, the teams were announced to the public, followed by the formalities which proceed a soccer match (national anthem, greeting the adversaries and the referees).

A CANON ${ }^{\circledR}$ camera (model SX60) was positioned on a tripod (height $-1.5 \mathrm{~m})$ in the stands $(\sim 3 \mathrm{~m}$ above the level of the field) of the stadium. In this way, both halves ( $\sim 45$ min) of the Pernambuco under-17 championship soccer match were recorded. All of the investigation procedures are described in Figure 1.

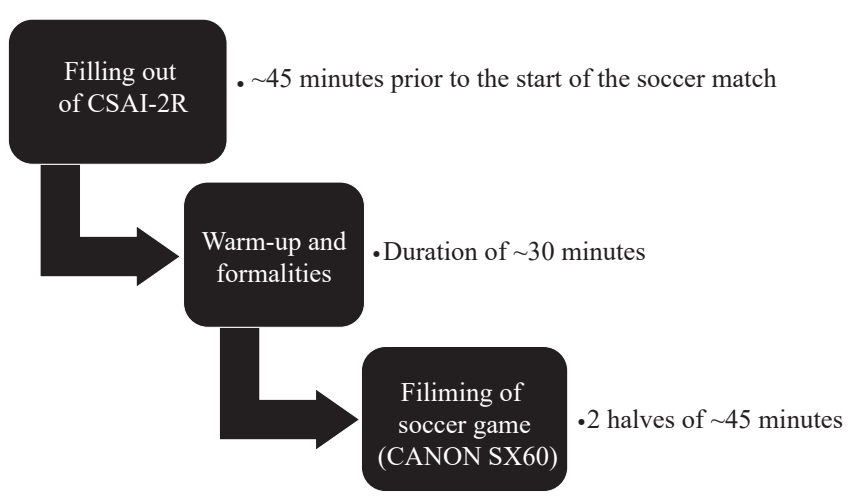

Figure 1. The investigation's experimental design. CSAI-2R = Competitive State Anxiety Inventory.

The data were collected in the local of the competition (soccer stadium). The players answered the CSAI-2R before the soccer match. The young athletes received the same verbal guidance, and any doubts were settled. Following that, the athletes played a match in the Pernambuco soccer championship, which was filmed. It is emphasized that only 2 professionals (experienced in the area of coaching soccer) analyzed each player's actions of passing the ball in the soccer match.

Data analysis. The Shapiro Wilk test for assessing data distribution was undertaken. Averages and standard deviations were used for describing the variables (Decision-making index passing, CSAI-2R, training program and age). The Pearson product-moment correlation coefficient was used to relate the subscales of the CSAI-2R (cognitive anxiety, somatic anxiety and self-confidence) to the Decision-making index passing. Forward linear regression was carried out to analyze the effect of the CSAI-2R (cognitive anxiety, somatic anxiety and self-confidence) on the Decision-making index - passing. All the data were treated using the SPSS software, version 21.0 (IBM Corp., Armonk, NY, USA), adopting the level of significance of $5 \%$. 


\section{Ethical Considerations}

After receiving information about the procedures that they would undergo, the participants signed the terms of assent. The athletes' coaches signed the TFIC, agreeing with the methodological procedures of the investigation. The procedures adopted in this study complied with the rules of Resolution 466/12 of the National Health Council for research involving human beings. The project was approved by the Committee for Ethics in Research with Human Beings of the Universidade Federal de Pernambuco (CAAE 46978515.6.0000.5208).

\section{Results}

The descriptive data (CSAI-2R, the decision-making index - passing, weekly training program - weekly frequency of training $\mathrm{x}$ hours of training per day - and age) are shown in Table 1.

Table 1

Descriptive values (average and standard deviation) of the study's variables

\begin{tabular}{lcc}
\hline Variables & Average & $\begin{array}{c}\text { Standard } \\
\text { Deviation }\end{array}$ \\
\hline CSAI-2R & 30.76 & 12.05 \\
Decision-making Index (pass) & 0.52 & 0.09 \\
Weekly training program (hours) & 8.33 & 0.71 \\
Age (years) & 16.63 & 0.42 \\
\hline
\end{tabular}

Table 2 indicates the values of correlations between the subscales of the CSAI-2R and the decision-making index passing. Negative correlations were found for the "cognitive anxiety" and the "somatic anxiety" subscales of the CSAI$2 \mathrm{R}$ with the decision-making index. In contrast, a positive correlation was found between the "self-confidence" subscale of the CSAI-2R and the decision-making index.

Table 2

Relationship between the subscales of the CSAI-2R and thedecision-making index

\begin{tabular}{lc}
\hline CSAI-2R subscales & Pass DMI \\
\hline Cognitive anxiety & $-0.44^{*}$ \\
Somatic anxiety & $-0.42^{*}$ \\
Self-confidence & $0.37^{*}$ \\
\hline
\end{tabular}

Note. CSAI-2R = Competitive State Anxiety Inventory; DMI = decision-making index; ${ }^{*} p<0.05$.

The linear regression model may be observed in Table 3. The results indicated a significant influence of cognitive anxiety $\left(F_{(1,39)}=53.01\right.$; Wilks's Lambda $=0.89$; $\left.R^{2}=0.20 ; p=0.001\right)$, inserted in block 1 . An increase was revealed in the scale of the influence in block 2 , when somatic anxiety was included in the model $\left(F_{(2,38)}=69.44\right.$; Wilks's Lambda $=0.94 ; R^{2}=0.45 ; p=0.001$ ). Self-confidence, inserted in block 3 , was also shown to influence the decisionmaking index - passing $\left(F_{(3,37)}=78.18\right.$; Wilks's Lambda $=0.95$; $\left.R^{2}=0.31 ; p=0.001\right)$.

Table 3

Linear regression, analyzing the influence of competitive anxiety (cognitive, somatic and self-confidence) on the variance of the passing decision-makingin soccer players

\begin{tabular}{lcccccc}
\hline Variable & Block & $B$ & $\mathrm{R}$ & $\mathrm{R}^{2}$ & $\mathrm{R}^{2 *}$ & $p$ \\
\hline $\begin{array}{l}\text { Cognitive } \\
\text { Anxiety }\end{array}$ & 1 & 0.11 & 0.44 & 0.20 & 0.19 & 0.001 \\
$\begin{array}{l}\text { Somatic } \\
\text { Anxiety }\end{array}$ & 2 & 0.15 & 0.67 & 0.45 & 0.43 & 0.001 \\
Self-confidence & 3 & 0.16 & 0.77 & 0.59 & 0.56 & 0.001 \\
\hline
\end{tabular}

Note. $\mathrm{R}^{2 *}=\mathrm{R}^{2}$ adjusted.

\section{Discussion}

The investigation aimed to analyze the effect of competitive anxiety on passing decision-making young soccer players. In essence, the study's findings indicated the effect of cognitive anxiety, somatic anxiety and selfconfidence on passing decision-making in young soccer players, corroborating the present study's hypotheses.

Decision-making is considered to be a complex phenomenon, involving perception, anticipation, attention, memory and motor action (Afonso et al., 2012). Hence, decision-making includes both cognitive ("what to do") and motor ("how to do it") components. Soccer is indicated to be a dynamic, unpredictable sport (Müller et al., 2016), requiring appropriate decisions due to the situational changes - which are constant during the game. The fundamental principles of soccer are: passing, shooting, ball control, heading, dribbling, feinting and tackling (Praça, Custódio, \& Greco, 2015). According to Memmert (2010), passing is the main foundation to be successful in soccer. It should be highlighted, however, that the soccer player, upon receiving the ball, should not have developed adequately the cognitive components of decision-making (perception, anticipation and memory) over his or her career, even if skillful in technical terms, may not choose the best passing option.

Considering passing decision-making, the present study's findings revealed the effect of cognitive anxiety. Block 1 of the regression model explained $20 \%$ of the variance in passing decision-making. This result indicates that $20 \%$ of the decisions made in executing the pass were influenced by the negative expectations in relation to performance as expressed shortly before the match. Indeed, studies have demonstrated that cognitive anxiety is related negatively to sporting performance (Patel, Omar, \& Terry, 2010; Rathschlag \& Memmert, 2015; Sonoo, Gomes, Damasceno, Silva, \& Limana, 2010). It may 
be that negative thoughts regarding sporting performance prior to the occurrence of the competition, in some way, may inhibit the speed at which the player processes information, which may reduce the probability of making the appropriate decision. An alternative explanation for the results of block 1 of the linear regression model relates to the possibility of negative thoughts shortly before the competition diminishing the player's focus of attention, which, in its turn, may allow irrelevant stimuli associated with the game (for example, the fans and the media) to disrupt passing decision-making.

Regarding somatic anxiety, the present study's results explained $25 \%$ of the variance in the passing decisionmaking. This finding means that $25 \%$ of the decisions in carrying out the pass were influenced by the responses of the autonomous nervous system (for example, cardiac frequency, sweating, muscle tension and body temperature) directed at the stressor event (for example, the semifinals of the Pernambuco under-17 category soccer championship). Studies have indicated an inversely proportional relationship between somatic anxiety and sporting performance (Millet, Groslambert, Barbier, Rouillon, \& Candau, 2005; Silva et al., 2014). Indeed, somatic anxiety entails an increase in cardiac frequency and muscle tension (Andersen \& Calatayud, 2016; Zhang, Si, Chung, \& Gucciardi, 2016). Scientific findings have demonstrated that increase in cardiac frequency before and/or during a competitive event can cause overload of the cardiovascular system, with negative repercussions in the athletes' performance (Medeiros, Tonello, Gasparini, Foster, \& Boullosa, 2016). Likewise, increase in muscle tension before the competition can cause fatigue to begin earlier, resulting in impairment of the athletes' performance (Martens et al., 1990). It is highlighted that physiological fatigue is closely related to mental fatigue (Zhang et al., 2016). In this regard, both cardiovascular overload and muscle tension can - even if indirectly - diminish the athletes' cognitive performance, which, in a certain way, may explain the findings of block 2 of the regression model in the present study.

Self-confidence, in its turn, explained $14 \%$ of the variance in the passing decision-making. This result reveals that $14 \%$ of the decisions behind the passes were influenced by the self-confidence as measured before the competition. The theoretical model of Martens et al. (1990) indicates a linear and positive relationship with sporting performance, partly corroborating the findings of block 3 of the regression model. Patel et al. (2010) evidenced that athletes with high levels of self-confidence obtained better sporting results. Furthermore, the findings of the study of Fernandes et al. (2014) indicated that self-confidence was closely related to the performance of amateur athletes. In this regard, it seems that the athlete's level of self-confidence may cause a positive effect in his or her competitive performance. However, above all, it is emphasized that none of the above-mentioned studies (Fernandes et al., 2014; Patel et al., 2010) analyzed the relationship of self-confidence with cognitive performance.

Although the design of the present investigation was unprecedented with young soccer players, the results must be analyzed with caution, considering that the study has limitations, which must be mentioned. No instrument was used for measuring the physiological indicators of somatic anxiety (for example, cardiac frequency and electromyography). Hence, it cannot be stated that the athletes' autonomous nervous systems were highly activated prior to the match, even if high scores were shown in the CSAI-2R. Neither were the technical movements in the undertaking of the pass controlled for. In this regard, performance in the GPAI test must be analyzed with care, given that some passes may have been interpreted as inappropriate due to the incorrect use of the technique, although the decision made (cognitive component of the decision-making) may have been appropriate.

The present study's findings allow one to conclude that anxiety may be considered to be an intervening factor in passing decision-making of young male soccer players. From the practical point of view, the present study indicates that cognitive and somatic anxiety may prevent the young soccer player from appropriate passing decision-making during the competition.

\section{References}

Afonso, J., Garganta, J., \& Mesquita, I. (2012). A tomada de decisão no desporto: O papel da atenção, da antecipação e da memória [Decision-making in sports: The role of attention, anticipation and memory]. Revista Brasileira de Cineantropometria e Desempenho Humano, 14(5), 592-601. doi:10.5007/1980-0037.2012v14n5p592

Andersen, L. L., \& Calatayud, J. (2016). Mind-muscle connection revisited: Do 100 studies about beanbag tossing, stick balancing, and dart throwing have any relevance for strength training? European Journal of Applied Physiology, 116(4), 865-866. doi:10.1007/ s00421-016-3342-x

Araújo, D., Davids, K., Diniz, A., Rocha, L., Santos, J. C., Dias, G., \& Fernandes, O. (2015). Ecological dynamics of continuous and categorical decision-making: The regatta start in sailing. European Journal of Sport Science, 15(3), 195-202. doi:10.1080/17461391.2014.928749

Borges, P. H., Avelar, A., \& Rinaldi, W. (2015). Conhecimento tático processual, desempenho físico e nível de maturidade somática em jovens jogadores de futebol [Tactical knowledge process, physical performance and level of somatic maturation in young soccer players]. Revista Brasileira de Ciência e Movimento, 23(3), 88-96. Retrieved from https://portalrevistas.ucb.br/index.php/ RBCM/article/view/5187/4000

Davids, K., Araújo, D., Correia, V., \& Vilar, L. (2013). How small-sided and conditioned games enhance acquisition of movement and decision-making skills. Exercise and Sport Sciences Reviews, 41(3), 154-161. doi:10.1097/ JES.0b013e318292f3ec 
Fernandes, M. G., Nunes, S. A., Raposo, J. V., \& Fernandes, H. M. (2014). Efeitos da experiência nas dimensões de intensidade, direção e frequência da ansiedade e autoconfiança competitiva: Um estudo em atletas de desportos individuais e coletivos [Effects of experience on the dimensions of intensity, direction and frequency of the competitive anxiety and self-confidence: A study in athletes of individual and team sports]. Motricidade, 10(2), 81-89. doi:10.6063/motricidade.10(2).2930

Fernandes, M. G., Nunes, S. A., Raposo, J. V., Fernandes, H. M., \& Brustad, R. (2013). The CSAI-2: An examination of the instrument's factorial validity and reliability of the intensity, direction and frequency dimensions with Brazilian athletes. Journal of Applied Sport Psychology, 25(4), 377-391. doi:10.1080/10413200.2012.744780

Fortes, L. S., Lira, H. A. A. S., Lima, R. C. R., Almeida, S. S., \& Ferreira, M. E. C. (2016). Mental training generates positive effect on competitive anxiety of young swimmers? Revista Brasileira de Cineantropometria e Desempenho Humano, 18(3), 353-361. doi:10.5007/19800037.2016v18n3p353

Gonzaga, A. R., Albuquerque, M. R., Malloy-Diniz, L. F., Greco, P. J., \& Costa, I. T. (2014). Affective decision-making and tactical behavior of under-15 soccer players. Plos One, 9(6), e101231. doi:10.1371/journal.pone.0101231

Lopes, M. C., Magalhães, R. T., Diniz L. B. F., Moreira J. P. A., \& Albuquerque, M. R. (2016). The influence of technical skills on decision making of novice volleyball players. Revista Brasileira de Cineantropometria \& Desempenho Humano, 18(3), 362-370. doi:10.5007/19800037.2016v18n3p362

Martens, R., Vealey, R. S., \& Burton, D. (1990). Competitive anxiety in sport. Champaign, IL: Human Kinetics.

Matias, C. J.A. S., \& Greco, P. J. (2011). Conhecimento táticoestratégico dos levantadores brasileiros campeões de voleibol: Da formação ao alto nível [Knowledge tacticalstrategic of setter's champions Brazilian volleyball: Members of teams adolescent and adult high level]. Revista Brasileira de Educação Física e Esporte, 25(3), 513-535. doi:10.1590/S1807-55092011000300014

Medeiros, A. R., Tonello, L., Gasparini, N., Foster, C., \&Boullosa, A. D. (2016). Lowered heart rate response during competition in figure skaters with greater aerobic fitness. International Journal of Performance Analysis in Sport, 16(2), 581-590. doi:10.1080/24748668.2016.11868910

Memmert, D. (2010). Testing of tactical performance in youth elite soccer. Journal of Sports Science and Medicine, 9(2), 199-205. Retrieved from https:/www.ncbi.nlm.nih. gov/pmc/articles/PMC3761738/pdf/jssm-09-199.pdf
Memmert, D., \& Harvey, S. (2008). The Game Performance Assessment Instrument (GPAI): Some concerns and solutions for further development. Journal of Teaching in Physical Education, 27(2), 220-240.doi:10.1123/ jtpe.27.2.220

Millet, G. P., Groslambert, A., Barbier, B., Rouillon, J. D., \& Candau, R. B. (2005). Modelling the relationships between training, anxiety, and fatigue in elite athletes. International Journal of Sports Medicine, 26(6), 492-498.doi:10.1055/s-2004-821137

Müller, E., Garganta, J., Santos, R. M. M., \& Teoldo, I. (2016). Comportamento e desempenho táticos: Estudo comparativo entre jogadores de futebol e futsal. Revista Brasileira de Ciência e Movimento, 24(2), 100-109. Recuperado de https://portalrevistas.ucb.br/index.php/ RBCM/article/view/6088/4399

Oslin, J. L., Mitchell, S. A., \& Griffin, L. L. (1998). The Game Performance Assessment Instrument (GPAI): Development and preliminary validation. Journal of Teaching in Physical Education, 17(2), 231-243.

Patel, D. R., Omar, H., \& Terry, M. (2010). Sport-related performance anxiety in young female athletes. Journal of Pediatric and Adolescent Gynecology, 23(6), 325-335. doi:10.1016/j.jpag.2010.04.004

Pedro, R. E., Machado, F. A., \& Nakamura, F. Y. (2014). Efeito do número de jogadores sobre a demanda física e respostas fisiológicas durante jogos com campo reduzido em jogadores de futebol sub-15 [Effect of the number of players on physical demand and physiological responses during games with small-sided soccer players U-15]. Revista Brasileira de Educação Física e Esporte, 28(2), 211-219. doi:10.1590/1807-55092014000200211

Praça, G. M., Custódio, I. J. O., \& Greco, P. J. (2015). Numerical superiority changes the physical demands of soccer players during small sided games. Revista Brasileira de Cineantropometria \& Desempenho Humano, 17(3), 269-279. doi:10.5007/1980-0037.2015v17n3p269

Rathschlag, M., \& Memmert, D. (2015). Self-generated emotions and their influence on sprint performance: An investigation of happiness and anxiety. Journal of Applied Sport Psychology, 27(2), 186-199. doi:10.1080/ 10413200.2014.974783

Romeas, T., Guldner, A., \&Faubert, J. (2016). 3D-Multiple Object Tracking training task improves passing decision-making accuracy in soccer players. Psychology of Sport and Exercise, 22, 1-9. doi:10.1016/j. psychsport.2015.06.002

Silva, M. M. F., Vidual, B. P., Oliveira, R. A., Yoshida, H. M., Borin, J. P., \& Fernandes, P. T. (2014). Ansiedade e desempenho de jogadoras de voleibol em partidas realizadas dentro e fora de casa [Anxiety and performance in volleyball players in matches realized inside and outside home]. Revista da Educação Física/UEM, 25(4), 585-596. doi:10.4025/reveducfis.v25i4.24347 
Sonoo, C. N., Gomes, A. L., Damasceno, M. L., Silva, S. R., \& Limana, M. D. (2010). Ansiedade e desempenho: Um estudo com uma equipe infantil de voleibol feminino [Anxiety and performance: A study of an infant female volleyball team]. Motriz: Revista de Educação Física, 16(3), 629-637. doi:10.5016/1980-6574.2010v16n3p629

Wallace, J. L., \& Norton, K. I. (2014). Evolution of World Cup soccer final games 1966-2010: Game structure, speed and play patterns. Journal of Science and Medicine in Sport, 17(2), 223-228. doi:10.1016/j. jsams.2013.03.016

Zhang, C.-Q., Si, G., Chung, P.-K., \& Gucciardi, D. F. (2016). Mindfulness and burnout in elite junior athletes: The mediating role of experiential avoidance. Journal of Applied Sport Psychology, 28(4), 437-451. doi:10.1080/ 10413200.2016.1162223

Leonardo de Sousa Fortes is a Professor of the Programa de Pós-Graduação em Educação Física of the Universidade Federal de Pernambuco.

Raphaella Christinne Ribeiro de Lima is a Master candidate of the Programa de Pós-Graduação em Educação Física of the Universidade Federal de Pernambuco.

Sebastião Sousa Almeida is a full Professor of the Faculdade de Filosofia, Ciências e Letras de Ribeirão Preto of the Universidade de São Paulo.

Romulo Maia Carlos Fonseca is a Professor of the Programa de Pós-Graduação em Educação Física of the Universidade Federal de Pernambuco.

Pedro Pinheiro Paes is a Professor of the Programa de PósGraduação em Educação Física of the Universidade Federal de Pernambuco.

Maria Elisa Caputo Ferreira is a Professor of the Universidade Federal de Juiz de Fora.

Received: Oct. 20, 2016

1st Revision: Jan. 24, 2017

Approved: Mar. 29, 2017

How to cite this article:

Fortes, L. S., Lima, R. C. R., Almeida, S. S., Fonseca, R. M. C., Paes, P. P., \& Ferreira, M. E. C. (2018). Effect of competitive anxiety on passing decision-making in under-17 soccer players. Paidéia (RibeirãoPreto), 28, e2820. doi:http://dx.doi.org/10.1590/1982-4327e2820 